\title{
PENERAPAN KURIKULUM 2013 PADA MATA PELAJARAN SEJARAH PADA SEKOLAH MENENGAH ATAS
}

Oleh: Danu Eko Agustinova

Universitas Negeri Yogyakarta

Email: danu_eko@uny.ac.id

\begin{abstract}
ABSTRAK
Penelitian ini bertujuan untuk mengkaji: (1) penerapan kurikulum 2013 dibeberapa sekolah di indonesia, (2) kedudukan mata pelajaran sejarah dalam kurikulum 2013, dan (3) evaluasi penerapan mata pelajaran sejarah pada kurikulum 2013 yang ada dibeberapa sekolah menegah atas di indonesia. Penelitian ini menggunakan metode kajian literatur dan penelitian kualitatif dengan data sekunder dalam mendapatkan sumber-sumber data untuk penyusunannya. Hasil penelitian menunjukkan: (1) kurikulum 2013 merupakan kurikulum yang berbasis kompetensi dan karakter, (2) sejarah merupakan mata pelajaran yang mendapatkan amanat sebagai mata pelajaran pendidikan karakter dalam kurikulum 2013, (3) dalam penerapannya, mata pelajaran sejarah telah berhasil menjalankan amanat kurikulum 2013 yang berbasis pada kompetensi dan karakter, akan tetapi di dalam penerapannya terdapat hal-hal yang masih perlu diperbaiki dan ditingkatkan, seperti sarana prasarana, metode pembelajaran, dan lain sebagainya.
\end{abstract}

Kata kunci: kurikulum 2013, mata pelajaran sejarah, sekolah menengah atas

\section{PENDAHULUAN}

Pada dasarnya pendidikan merupakan landasan dalam membangun sebuah bangsa. Maju dan mundurnya suatu bangsa dapat dilihat dari kualitas pendidikan. Bangsa yang memiliki basis pendidikan yang berkualitas akan mampu menghasilkan sumber daya manusia yang berkualitas pula. Sehingga mampu membawa bangsanya menjadi bangsa yang maju, unggulan bermartabat. Begitu juga sebaliknya suatu bangsa yang mundur dalam pendidikan, maka tidak akan maju dalam pembangunan. Hingga saat ini indonesia telah melakukan beberapa kali pergantian kurikulum pembelajaran. Tujuan dari pergantian kurikulum tersebut adalah untuk menyesuaikan dengan perkembangan zaman. Kurikulum 2013 merupakan kurikulum yang digadang-gadang akan menjadi kurikulum yang dapat menjawab tantangan dimasa depan.

$$
\text { Zia Ulhaq (2017: 1-2) }
$$

Pemerintah Indonesia, melalui Kementerian Pendidikan Dasar dan Menengah menggelar dan menetapkan sejarah sebagai sebuah mata pelajaran yang penting dalam kurikulum 2013, khususnya bagi pendidikan tingkat menengah atas (SMA-sederajat). Mata pelajaran Sejarah Indonesia pada tingkat SMA merupakan sebuah mata pelajaran kelompok wajib A, yang berarti mata pelajaran tersebut wajib 
diambil oleh seluruh jenis sekolah menengah tingkat atas yang berada di lingkup Kementerian Pendidikan Dasar dan Menengah dan Kementerian Agama. Selain menjadi mata pelajaran wajib, terdapat pula mata pelajaran sejarah yang termasuk dalam kelompok peminatan ilmu-ilmu sosial, bahasa dan menjadi pelajaran lintas minat.

Pembagian mata pelajaran sejarah Indonesia dan sejarah tidaklah dikenal dalam kurikulum sebelumnya (KTSP) Pemisahan mata pelajaran tersebut barulah dilakukan dalam Kurikulum 2013. Kurikulum yang mulai diterapkan semenjak taun 2013 dan sudah beberapa kali mengalami revisi dengan maksud untuk penyempurnaan kurikulum. Sebagai kurikulum baru, tentu terdapat keunggulan dan tantangan dalam penerapan kurikulum tersebut. Melalui penelitian ini, penulis ingin mengungkapkan sejauhmana kesiapan beberapa Sekolah Menengah Atas di Indonesia dalam penerapan kurikulum 2013 khususnya pada mata pealajaran sejarah.

\section{KAJIAN PUSTAKA}

1. Kurikulum 2013

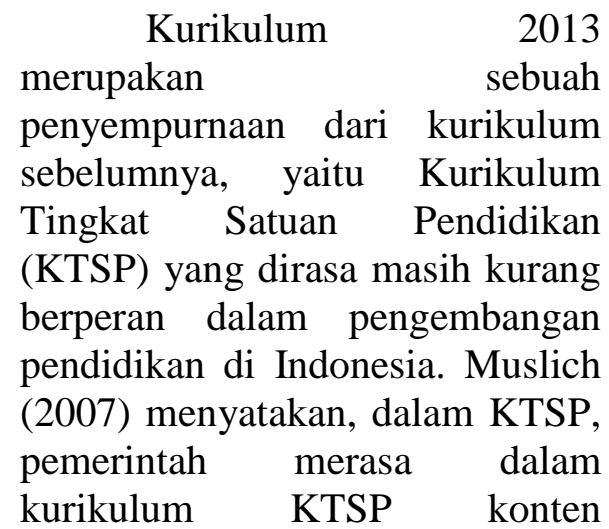

kurikulum masih terlalu padat yang ditunjukkan dengan banyaknya mata pelajaran dan banyak materi yang keluasan dan tingkat kesukarannya melampaui tingkat perkembangan usia anak. Sedangkan Hidayat (2013) mengemukakan bahwasanya Kurikulum 2013 merupakan sebuah kurikulum yang mengedepankan pada sikap dan perilaku peserta didik, pada hakikatnya kurikulum ini menginginkan manusia Indonesia yang berakhlak mulia juga pandai dalam berbuat dan berfikir.

2. Mata Pelajaran Sejarah

Dalam kurikulum 2013 mata pelajaran sejarah memiliki posisi yang sangat penting dalam kehidupan berbangsa dan bernegara. Mata pelajaran sejarah mendapat amanah untuk membentuk karakter peserta didik lewat nilai-nilai yang terkandung didalamnya. Kedudukan sejarah dalam ilmu pengetahuan yakni sebagai ilmu sosial. Ditinjau dari usianya, sejarah termasuk ilmu sosial tertua yang embrionya telah ada dalam bentuk-bentuk mitos dan tradisi-tradisi dari manusia yang hidup paling sederhana (Gee, 1950: 36, Sjamsuddin, 1996: 190). Sejarah dimasukan kedalam golongan ilmu sosial dikarenakan sejarah mempelajari perilaku sosial. Itu sebabnya dalam pembelajaran sejarah kajiankajiannya selalu dituntut pendekatan-pendekatan 
inter/multidisipliner karena tidak cukup dengan kajian sejarah naratif dapat menjelaskan aspekaspek sosial yang melingkupinya dapat dieksplanasikan.

\section{METODE PENELITIAN}

Dalam melakukan penulisan penelitian ini, penulis melakukan teknik penyusunan yang sistematis untuk memudahkan langkah-langkah yang akan diambil. Metode yang digunakan penulisan untuk menyusun penelitian ini yakni dengan melakukan studi literatur. Studi literatur adalah mencari referensi teori yang relefan dengan kasus atau permasalahan yang ditemukan (Anonim. 2018: 43). Referensi tersebut memuat hal tentang: (a) pengertian pendidikan secara umum, (b) pengertian kurikulum secara umum, (c) kurikulum 2013, dan (d) mata pelajaran sejarah dalam kurikulum 2013. Referensi ini dapat dicari dari buku, jurnal, artikel laporan penelitian, dan situs-situs di internet yang membahas Kurikulum 2013. Data yang didapat dari studi literatur ini akan digunakan sebagai acuan untuk penulisan penelitian (Yulius. 2014: 29).

Berdasarkan sifat dan spesifikasi yang diangkat dalam penelitian ini, maka penelitian ini juga menggunakan pendekatan deskriptif kualitatif dengan menggunakan data sekunder. Tujuan penelitian deskriptif ini adalah untuk membuat pencandraan secara sistematis, faktual, dan akurat mengenai fakta-fakta dan sifat-sifat populasi atau daerah tertentu (Sugiyono. 2012: 12). Sedangkan data sekunder merupakan data tertulis yang dapat diperoleh dari buku, majalah ilmiah, arsip dari instasi, laporan pertanggung jawaban program, maupun dokumen resmi seperti hasilhasil studi, tesis, hasil survei, studi historis, sumber internet, dan sebagainya (Lexy J. Moleong. 2009:153). Adapun sumber data yang dikategorikan sebagai sumber data sekunder dalam penelitian ini adalah buku, journal, skripsi, tesis, dan artikel ilmiah yang memiliki kaitan dengan kurikulum 2013.

\section{PEMBAHASAN}

Kurikulum 2013 merupakan kurikulum berbasis kompetensi dan karakter. Kurikulum 2013 bukan merupakan hal yang baru, tapi kurikulum 2013 adalah kurikulum yang merupakan rujukan dari kurikulum sebelumnya yaitu Kurikulum Berbasis Kompetensi (KBK) ke Kurikulum Tingkat Satuan Pendidikan (KTSP). Jiwa kurikulum 2013 diyakini memiliki posisi yang kokoh untuk mengantar generasi Indonesia sebagai generasi emas pada tahun 2045 mendatang. Oleh karena itu, kurikulum ini disesuaikan dengan batas-batas tertentu yang dapat diharapkan menjadi jawaban atas berbagai tantangan. Pengembangan Kurikulum 2013 juga menekankan penyempurnaan pola pikir, penguatan tata kelola kurikulum, pendalaman dan perluasan materi, penguatan proses pembelajaran, dan penyesuaian beban belajar agar dapat menjamin kesesuaian antara apa yang diinginkan dengan apa yang dihasilkan (Anonim, 2013).

Kelebihan Kurikulum 2013 tahapan-tahapan pendekatan scientific 
ini tidak hanya ada pada desain Kurikulumnya tetapi juga sampai di depan, karena dalam RPP sudah dirancang untuk melaksanakan tahapan-tahapan tersebut. Dalam konteks mata pelajaran sejarah, pada Kurikulum 2013 di organisasi isi juga terdapat inovasi dan perubahan yang boleh dikatakan spektakuler, yaitu mapel (mata pelajaran) Sejarah Indonesia sebagai mapel wajib untuk sekolah menengah, baik SMA/MA maupun SMK/MAK dan ada mapel Sejarah sebagai salah satu mapel pada peminatan ilmu-ilmu Sosial. Dikatakan spektaluler karena selama ini oleh masyarakat dan juga peserta didik pada umumnya mapel Sejarah itu perupakan pelajaran yang tidak penting dan cenderung menjemukan (Anonim, 2013).

Sejarah adalah mata pelajaran yang menanamkan pengetahuan dan nilai-nilai mengenai proses perubahan dan perkembangan masyarakat indonesia dan dunia pada masa lampau hingga kini (Isjoni, 2007: 71). Pembelajaran sejarah adalah suatu kegiatan yang dilakukan oleh guru untuk membantu siswa dalam memperoleh pengetahuan dan pengalaman dari masa lalu, sehingga mereka dapat bersikap, bertindak dan bertingkahlaku dengan perspektif kebijaksanaan (Isjoni, 2007:56). Dengan pembelajaran sejarah diharapakan siswa mampu berpikir secara kronologis sehingga siswa dapat memahamii perkembangan dan perubahan masyarakat agar memperoleh pelajaran yang dapat digunakan dalam kehidupanya.
Mata pelajaran sejarah merupakan mata pelajaran yang mendapatkan amanat sebagai mapel pendidikan karakter di dalam kurikulum 2013. Tentu saja hal ini merupakan angin segar dan juga menjadi amanat yang besar bagi guru sejarah. Inovasi penting yang dikembangkan dalam mapel Sejarah Indonesia dan Sejarah adalah kontinuitas pembelajaran antara sejarah nasional dan sejarah lokal. Sejarah nasional menjadi payung untuk mengenal bangsa dan sejarah lokal untuk mengenal masyarakat di sekitarnya serta keduanya merupakan peristiwa yang terkait satu dengan lainnya. Kejadian dalam peristiwa sejarah nasional diikuti dan diperkuat oleh gerak sejarah lokal. Selain itu, melalui pelajaran sejarah, peserta didik diajak untuk melihat keberlanjutan dan perubahan yang terjadi dalam masyarakat dan bangsa yang terkait dengan perkembangan sejarah. (Anonim. 2016).

Pembelajaran pada mata pelajaran sejarah menggunakan pendekatan pembelajaran berbasis peserta didik aktif (active learning). Pendekatan pembelajaran ini lebih memungkinkan memberikan kesempatan bagi peserta didik untuk melakukan pembelajaran agar lebih memungkinkan memberikan kesempatan bagi peserta didik untuk melakukan pembelajaran agar lebih bermakna. Pembelajaran agar lebih bermakna jika peserta didik mengalami sendiri setiap proses pembelajaran melalui aktivitas yang aktif dan dapat menggunakannya sehari-hari. 
Pengetahuan peserta didik bukan berasal dari informasi guru namun berasal dari usaha eksplorasi informasi peserta didik sendri melalui aktivitas pembelajaran yang dilakukan.

Beberapa prinsip yang perlu diperhatikan dalam pembelajaran sejarah di SMA/MA adalah:

1. Pembelajaran Sejarah didasarkan atas kesinambungan apa yang terjadi di masa lampau dengan kehidupan masa kini, antara peristiwa sejarah tingkat nasional dan tingkat lokal, dan pemahaman peristiwa sejarah di tingkat lokal berdasarkan keutuhan suatu peristiwa sejarah.

2. Dalam mengembangkan pemahaman mengenai kesinambungan antara apa yang terjadi di masa lampau dengan kehidupan masa kini, dalam tugas untuk setiap periode sejarah peserta didik diarahkan agar mampu menemukan peninggalan fisik (terutama artefak) dan peninggalan abstrak (tradisi, pikiran, pandangan hidup, nilai, kebiasaan) di masyarakat yang diwarisi dari peristiwa sejarah pada suatu periode.

3. Dalam mengembangkan keterkaitan antara peristiwa sejarah di tingkat nasional dan tingkat lokal, dalam tugas setiap peserta didik diarahkan untuk mengkaji peristiwa sejarah sejak masa pergerakan nasional, dan membuat analisis mengenai keterkaitan dan sumbangan peristiwa tersebut terhadap peristiwa yang terjadi di tingkat nasional.
4. Mengembangkan proses pembelajaran dalam kemampuan keterampilah sejarah di semester awal sehingga peserta didik memahami konsep-konsep utama sejarah, menguasai keterampilah dasar sejarah, dan memantapkan penggunaan konsep utama dan keterampilan dasar ketika mereka mempelajari berbagai peristiwa sejarah di semester berikutnya.

5. Setiap peristiwa sejarah di semester tiga dan seterusnya dapat dirancang sebagai kegiatan pembelajaran untuk satu semester dan bukan hanya merupakan kegiatan satu atau da pertemuan secara berurutan ntuk setiap satu pokok bahasan.

6. Proses pembelajaran sejarah memberi kesempatan kepada peserta didik untuk menggunakan berbagai sumber seperti buku teks, buku referensi, dokumen, narasumber, atau pun artefak sera memberi kesempatan yang luas untuk menghasilkan "her or his own histories" Borries, 2000 dalam Anonim, 2013).

Di dalam Kurikulum 2013 yang diterapkan tidak lagi ada istilah Standar Kompetensi Lulusan (SKL), tetapi menggunakan istilah Kompetensi Inti (KI) yang merupakan terjemahan atau operasionalisasi SKL dalam bentuk kualitas yang harus dimiliki siswa setelah menyelesaikan pendidikannya. Kompetensi utama yang harus dimiliki siswa dikelompokkan dalam aspek sikap, pengetahuan, dan keterampilan (afektif, kognitif, dan psikomotor). Kompetensi Inti menggambarkan 
kualitas yang seimbang antara pencapaian hardskills dan soft skills. Dari KI tersebut dijabarkan kembali dalam Kompetensi Dasar (KD) yang berisi konten atau kompetensi mata pelajaran yang harus dikuasai peserta didik.

KI dirancang dalam empat kelompok yang saling terkait, yatu berkenaan dengan sikap keagamaan yang termuat dalam kompetensi inti 1 , sikap sosial pada kompetensi inti 2 , pengetahuan pada kompetensi 3, dan penerapan pengetahuan pada kompetensi inti 4. Keempat kelompok itu menjadi acuan dari Kompetensi Dasar dan harus dikembangkan dalam setiap peristiwa pembelajaran secara integratif. Kompetensi yang berkenaan dengan sikap keagamaan dan sosial dikembangkan secara tidak langsung (indirect teaching), yaitu pada waktu peserta didik belajar tentang pengetahuan dan penerapan pengetahuan. (Intan Permatasari, dkk. 2014: 20-21).

Penelitian yang dilakukan oleh Intan Permatasari, Leo Agung, dan Saeful Bachri di SMA MTA Surakarta yang didasarkan pada Rencana Pelaksanaan Pembelajaran (RPP) kurikulum 2013 yang berorientasi pada kompetensi inti. Pelaksanaan pembelajaran sejarah yang didasarkan pada kompetensi inti Kurikulum 2013 di SMA MTA Surakarta dilakukan melalui tiga tahap, yaitu kegiatan pendahuluan, kegiatan inti, dan kegiatan penutup. Hal tersebut sesuai dengan pendapat Hidayat (2013:126) menyatakan bahwa pada umumnya, pembelajaran sejarah berbasis kurikulum 2013 harus terdapat 5 hal penting dalam prosesnya, yaitu Mengamati, Menanya, Mengolah, Menyajikan, Menyimpulkan, dan Mencipta.

Hasil

menununjukkan bahwa proses pembelajaran di SMA MTA Surakarta telah memenuhi keempat kompetensi inti yang ada didalam kurikulum 2013. Kompetensi inti yang pertama tercermin dari jawaban salam dari peserta didik untuk guru dan peserta didik membaca Al-Qur'an secara bersama-sama terlebih dahulu sebelum pembelajaran dimulai. Kompetensi inti kedua yang tercermin dari sikap peserta didik dalam menghargai temannya yang berbicara atau sedang menyampaikan pendapat serta sopan terhadap kritik. Kompetensi inti ketiga tercermin dari keaktifan peserta didik dalam mencari informasi, berdiskusi, dan mengerjakan tugas. Disini guru hanya bertindak sebagai fasilitator dari peserta didik. Kemudian kompetensi inti yang terakhir tercermin dari kecakapan peserta didik dalam menyampaikan presentasi serta menjawab pertanyaan dari temanteman atau gurunya.

Sama halnya dengan penelitian yang dilakukan di SMA N 1 Bangsri Jepara. Hasil penelitian yang dilakukan oleh Khoirul Afif menunjukkan bahwa pemahaman pendidik terhadap kurikulum 2013 sudah baik. Menurut penelitian yang dilakukan, guru di SMA N 1 Bangsri menyadari bahwa yang menjadi ciri khas dari kurikulum 2013 adalah pendidikan karakter. Peserta didik diberikan kebebasan 
untuk mengeksplorasi kemampuannya dan guru hanya bertindak sebagai fasilitator. Dalam kurikulum 2013 ini juga dikembangkan model-model pembelajaran dengan pendekatan saintifik yang didalamnya ada tiga model pembelajaran, yakni model pembelajaran berbasis masalah (problem based learning),model pembelajaran berbasis proyek (project based learning), model pembelajaran penemuan (discovery learning).

Didalam penerapannya, mata pelajaran sejarah yang ada didalam kurikulum 2013 juga mengalami beberapa kendala atau tantangan. Tantangan tersebut diantaranya sebagai berikut.

1. Dalam menjalankan proses pembelajaran yang sesuai dengan kurukulum 2013 yaitu kegiatan belajar yang aktif dan interaktif antara siswa dengan siswa atau siswa dengan guru karena jika kemampuan siswa berbeda maka hanya akan beberapa siswa yang aktif sedangkan dalam kurikulum 2013 siswa dituntut agar lebih aktif berbicara dan mencari informasi sehingga dengan hal ini guru perlu waktu untuk memberi pemahaman kepada siswa.

2. kemampuan berbicara dan menulis ada kondisi lain yang menghambat proses pembelajaran yaitu kemampuan ekonomi siswa yang berbeda-beda.

3. Model-model pembelajaran berbasis proyek tentunya membutuhkan biaya untuk membeli alat-alat seperti handphone, laptop dan sebagainya kalau didaerah perkotaan mungkin itu tidak terlalu menjadi masalah namun didaerah pedesaan itu menjadi hal yang sulit selain masalah biaya juga mengenai masalah waktu, dalam mengerjakan tugas-tugas tersebut siswa tentunya membutuhkan waktu sedangkan di sekolah waktunya terbatas sehingga siswa harus mengerjakanya dirumah namun disisi lain jika siswa tidak diberi tugas kelompok maka tujuan kurikulum agar dapat membentuk pembelajaran interaktif akan tidak tercapai.

4. Sarana dan prasarana yang menunjang kegiatan belajar mengajar sangat minim, hal itu seperti LCD proyektor dan alat pendukungnya. (Khoirul Afif. 2015: 56-60).

\section{PENUTUP}

Berdasarkan hasil penelitian tersebut dapat diketahui bahwa kurikulum 2013 merupakan kurikulum berbasis kompetensi dan karakter. Kurikulum 2013 bukan merupakan hal yang baru, tapi kurikulum 2013 adalah kurikulum yang merupakan rujukan dari kurikulum sebelumnya yaitu Kurikulum Berbasis Kompetensi (KBK) ke Kurikulum Tingkat Satuan Pendidikan (KTSP). Kurikulum ini mulai terapkan pada tahun 2013 hingga sekarang. Berbagai revisi telah dilakukan guna menyempurnakan kurikulum yang memiliki cirikhas pendidikan karakter tersebut. Sejarah merupakan mata pelajaran yang 
mendapatkan titipan dalam pendidikan karakter dalam kurikulum 2013. Hal ini dikarenakan, telah muncul kesadaran akan pentingnya menerapkan nilai-nilai sejarah sebagai upaya membentuk dan meningkatkan karakter peserta didik. Dalam penerapannya, mata pelajaran sejarah ternyata dapat memenuhi empat kompetensi inti yang menjadi pokok dalam kurikulum 2013. Nilai-nilai religius, penghormatan antar sesama, sikap kritis, dan juga aktif telah tumbuh didalam jiwa peserta didik melalui mata pelajaran ini. Akan tetapi, mata pelajaran sejarah didalam kurikulum 2013 mengalami berbagai kendala. Kendala-kendala tersebut berkaitan dengan metode belajar peserta didik, kondisi ekonomi peserta didik, hingga sarana dan prasarana yang mendukungnya. Misalnya, dalam penilaian peserta didik, guru Sejarah mengalami kesulitan. Pelaksanaan evaluasi pembelajaran belum terimplementasikan dengan baik karena para guru hanya melakukan satu teknik pengambilan data penilaian sikap dari sekian banyak teknik pengambilan nilai sikap bagi siswa. Penilaian pengetahuan dan ketrampilan banyak menggunakan teknik penilaian tes tertulis, pembuatan makalah, presentasi/unjuk kerja, dan kuis.

\section{DAFTAR PUSTAKA}

Anggit Setyo Prakoso, dkk. 2017. Fondasi-fondasi Pendidikan. Makalah. Universitas Negeri Yogyakarta: Yogyakarta.

Anonym. Tanpa tahun. Dalan http://digilib.its.ac.id/public/I TS-Undergraduate-51214201100038-bab3.pdf.

Diakses 26 Januari 2018.

- 2016. Mata Pelajaran Sejarah SMA berdasarkan Kurikulum 2013. Program Studi Pendidikan Seajarah. FKIP ULM.

Intan Permatasari, Leo Agung, dan Saiful Bachri. 2014. Implementasi Kompetensi Inti Kurikulum 2013 dalam Pembelajaran Sejarah (Studi Kasus di SMA MTA Surakarta). Dalam http://jurnal.fkip.uns.ac.id/ind ex.php/sejarah/article/view/5 161. Diakses 26 Januari 2018.

Khoirul Afif. 2015. Strategi Pembelajaran Sejarah SMA dalam Penerapan Kurikulum 2013 di Kelas X SMA N 1 BANGSRI Tahun Pelajaran 2014/2015. Skripsi. Universitas Negeri Semarang: Semarang.

Manik Rarasningtyas. 2017. Penerapan Teori Belajar 
Humanistik $\mathrm{Ki} \quad$ Hajar

Dewantara didalam Mata Pelajaran Sejarah SMA Arya Jeding Tulungagung Jawa Timur. Makalah. Universitas Negeri Yogyakarta: Yogyakarta.

S. Nasution. 2008. Asas-Asas Kurikulum. Jakarta: Bumi Aksara

Republik Indonesia. (2003). UndangUndang Republik Indonesia Nomor 20, Tahun 2003, tentang Sistem Pendidikan Nasional.

RR Anisa Khaura, dkk. 2017. Sisitem Pendidikan: Kajian Mengenai Pengaruh Kurikulum Pendidikan terhadap Kehidupan

Ekonomi, Sosial, dan Budaya. Makalah. Universitas Negeri Yogyakarta.

Yulius. $2014 . \quad$ Dalam http://digilib.unila.ac.id/2100 19/BAB\%20III.pdf. Diakses 26 Januari 2018.

Zainal Arifin. 2011. Konsep dan Model Penegmbangan Kurikulum. Bandung: Remaja Rosdakarya.

Zia Ulhaq, Tuti Nuriah, Murni Winarsih. 2017. Pembelajaran Sejarah Berbasis Kurikulum 2013 di SMA Kotamadya Jakarta Timur. Jurnal PENDIDIKAN SEJARAH Vol.6 No. 2. Hlm. $1-12$ 